\title{
A Century of SHOCKs: ThE EVOLUTION OF THE GERMAN CITY SIZE DISTRIBUTION 1925 - 1999
}

\author{
E. MAARTEN BOSKER \\ STEVEN BRAKMAN \\ HARRY GARRETSEN \\ MARC SCHRAMM
}

CESIFO WORKING PAPER NO. 1728

CATEGORY 10: EMPIRICAL AND THEORETICAL METHODS

MAY 2006

An electronic version of the paper may be downloaded

- from the SSRN website:

- from the RePEc website:

www.SSRN.com

- from the CESifo website:

www.RePEc.org

www.CESifo-group.de 


\title{
A Century OF SHOCKS: The EvOlution OF THE GERMAN CITY SIZE DISTRIBUTION 1925 - 1999
}

\begin{abstract}
The empirical literature on city size distributions has mainly focused on the USA. The first major contribution of this paper is to provide empirical evidence on the evolution and structure of the West-German city size distribution. Using a unique annual data set that covers most of the 20th century for 62 of West-Germany's largest cities, we look at the evolution of both the city size distribution as a whole and each city separately. The West-German case is of particular interest as it has undergone major shocks, most notably WWII. Our data set allows us to identify these shocks and provide evidence on the effects of these 'quasi-natural experiments' on the city size distribution. The second major contribution of this paper is that we perform unit-root tests on individual German city sizes using a substantial number of observations to analyze the evolution of the individual cities that make up the German city size distribution. Our main findings are twofold. First, WWII has had a major and lasting impact on the city size distribution. Second, the overall city size distribution does not adhere to Zipf's Law. This second finding is largely based on the results of unit root tests for individual cities to test for Gibrat's Law, the latter being a requirement for Zipf's Law to hold for the overall city-size distribution. Together these two findings are consistent with theories emphasizing increasing returns to scale in city growth.
\end{abstract}

JEL Code: R12, O18.

\author{
E. Maarten Bosker \\ Utrecht School of Economics \\ Utrecht University \\ Vredenburg 138 \\ 3511 BG Utrecht \\ The Netherlands \\ m.bosker@econ.uu.nl \\ Harry Garretsen \\ h.garretsen@econ.uu.nl
}

\author{
Steven Brakman \\ Faculty of Economics \\ University of Groningen \\ P.O. Box 800 \\ 9700 AV Groningen \\ The Netherlands \\ s.brakman@rug.nl \\ Marc Schramm \\ m.schramm@econ.uu.nl
}

February, 2006

We would like to thank Peter Koudijs for excellent research assistance. Please send all correspondence to Maarten Bosker. 


\section{Introduction}

City size distributions and the underlying city size dynamics have received considerable attention in the economic literature over the years. Several theories have been posited that offer explanations of the evolution of city sizes and the resulting city size distribution. With the appearance of more and more empirical work on the evolution of city size distributions, recent theories (e.g. Eeckhout, 2004, Rossi-Hansberg and Wright, 2005) try to explain the evolution of city size distribution in a way that is consistent with the empirical results. Empirical studies have in particular produced evidence for two interesting features of city size distributions. First, city size distributions are found to be remarkably stable over time and furthermore the hierarchy of the individual cities making up these distributions is very much stable, which suggests proportionate city growth, see for example Eaton and Eckstein (1997) and Black and Henderson (2003). The second stylized fact is that city size distributions are very well approximated by a Power Law in the upper tail of the distribution. A special case of which is better known as Zipf's law and has been found to hold for various countries, see o.a. Soo (2004) and Nitsch (2005).

These empirical regularities led to the development of city growth models, that try to explain these city size distributions. Either a stable city size distribution adhering to Zipf's law in the upper tail follows directly from the model (Gabaix, 1999, Eeckhout, 2004), or it is one of the possible outcomes of the model (RossiHansberg and Wright, 2005). These models have benefited substantially from the work of Gabaix (1999) who, building on earlier work by Simon (1955), showed that such a stable city size distribution follows naturally ${ }^{1}$ if individual city size growth adheres to Gibrat's law ${ }^{2}$.

Recent empirical papers on the evolution of the city size distribution, e.g. Black and Henderson (2003), Overman and Ioannides (2001), Ioannides and Overman (2003), Dobkins and Ioannides (2000), and Eeckhout (2004), all focus on the US experience. Besides some simple Zipf studies that do not look at distributional dynamics or evidence for Gibrat's law, the only two paper we know of that offer a thorough look at the distributional dynamics of city size distributions outside the USA are Eaton and Eckstein (1997) and Anderson and Ge (2005). The former provides evidence for France and Japan confirming the notion of a stable city size distribution whilst the latter shows that in case of China the city size distribution has been affected in a predictable way by government policies.

The contributions of this paper are three-fold. First, we examine the evolution of the city size distribution for West-Germany (from now on simply referred to as Germany). The interest in the German city size distribution can be dated back to as early as 1913 when the geographer Auerbach (1913), as one of the first, noted that the city size distribution could be approximated by a power law. For our empirical analysis we have constructed a unique data set of annual city population data for 62 of the largest cities in Germany over the period

\footnotetext{
${ }^{1}$ Córdoba, 2004 shows that Gibrat's law is a necessary condition for Zipf's law.

${ }^{2}$ This result was extended by Eeckhout, 2004 who shows that the whole city size distribution is lognormal when individual cities adhere to Gibrat's law, finding a Pareto distribution in the upper tail is just a good approximation of the true lognormal distribution and depends (as already noted by Gabaix, 1999) by the chosen cutoff point of city size that indicates which cities belong to the upper tail of the distribution.
} 
1925-1999. This data set allows us to describe the evolution of the German city size distribution quite accurately. Second, our annual data set allows us to perform univariate unit root tests for each individual city in order to find evidence on Gibrat's Law. The present paper is among the first to provide unit root tests for Gibrat's law that, given our extensive data set, do not suffer from low power problems that are plaguing unit root tests based on a limited number of observations. Third, the use of German data also offers a specific empirical view on the evolution of the city size distribution, namely that of the effect of large shocks to the urban system. In the time period under consideration German cities were subject to a number of large 'quasi-natural experiments' namely the heavy destruction of cities during WWII and the split and subsequent reunification with East-Germany. Our data set allows us to look at the impact of these 'quasi-natural experiments' in a much more dynamic fashion than our earlier papers (Brakman et al., 2004 and Bosker et al., 2005).

The effect of these large shocks on city growth can help to distinguish between several of the proposed theories regarding city size distributions. Following Davis and Weinstein (2002), the existing theories regarding the evolution of the urban system can be grouped into three different categories, i.e. increasing returns to scale, random growth and locational fundamentals. The models in all three categories predict a stable city size distribution in equilibrium, however the reaction to shocks is quite different across the three types of models. Models exhibiting increasing returns to scale, e.g. Fujita et al. (1999) and Henderson (1974), give rise to a stable distribution which is sensitive to shocks and which does not necessarily adhere to Zipf's law. A large shock has the potential to (radically) change the city size distribution. Models falling under the random growth category, e.g. Gabaix (1999), predict that shocks have a permanent effect on city sizes, but given that these shocks are distributed randomly over cities and mean- and variance-independent of city size, they will in the limit result in a city size distribution that adheres to Zipf's law in the upper tail. The effect of a large shock thus has no effect on the limiting city size distribution, it can however have a permanent impact on the relative position of cities within the distribution. Finally, the locational fundamentals approach suggests that the observed city size distribution is the result of fixed underlying locational fundamentals (1st nature geography). A large shock will now result in both the city size distribution as a whole and the relative position of cities within this distribution returning to their pre-shock state. Given the three categories' different reaction to large shocks, the 'quasi-natural experiments' that the German urban system was subjected to, provide a way to distinguish between the three competing views of city size evolution.

Our first main finding is that the German city size distribution is permanently affected by the World War II shock, more so than by other shocks. Cities that have been hit relatively hard due to the substantial bombings and the subsequent allied invasion do not recover the loss in relative size. After the war, the city size distribution does not revert to its pre-WWII level, but shifts to one characterized by a more even distribution of population over the cities in the sample. Compared to the impact of WWII, the separation from and later reunion with East-Germany has had much less impact on relative city sizes. Our second finding is that, once corrected for the heavy destruction during WWII, unit root tests for the validity of Gibrat's law reject Gibrat's law 
for about $75 \%$ of all cities. The overall evidence suggests that the locational fundamentals approach is not supported by our evidence, which is in contrast to the findings of Davis and Weinstein $(2002,2004)$ for Japan. The evidence for random growth is also rather weak, city size does not adhere to Gibrat's law for a substantial number of cities in our sample after correcting for the huge shock during WWII. The evidence does seem to comply best with the increasing returns to scale hypothesis.

Our paper is organized as follows. Section 2 describes our data set. Section 3 provides the dynamics of the city size distribution by means of Markov chain modelling, showing in particular the impact of WWII. In sections 4 and 5 we test for Zipf's law both directly by means of a Zipf regression and indirectly by providing evidence on the relevance of Gibrat's law for each of the cities in the sample. Next, section 6 looks more thoroughly at the impact of WWII on individual cities' relative size providing evidence in favor of a permanent impact of WWII on many of the cities in our sample. Finally, section 7 concludes.

\section{Data}

In constructing our data set, we first had to choose which cities to include in our sample. We choose to include those West-German cities in our data set that either had a population of over 50.000 inhabitants before the beginning of WWII or cities that were over the sample period classified as Großstädte, cities with a population of at least 100.000 people. This resulted in 81 cities, the same sample as used in Brakman et al. (2004) and Bosker et al. (2005). In those two studies the only requirement to be included in the analysis was that we had city population data for the years 1939, 1946 and 1963 (and possibly 1933). In the present study we only include cities for which we have annual population data for each year in the 1925-1999 period. In total 19 of the 81 West-German cities in our sample did not meet this requirement. We are therefore left with a data set that consists of 62 West-German cities over the period (see Appendix A for more information on the cities included in our sample). The 19 cities that were dropped from our analysis were mostly relatively small cities. Since a main point of our interest will be the upper tail of the city size distribution it can be argued that this exclusion does not matter too much for our analysis.

As to the decision to focus on West-German cities only, there are two main reasons to exclude East-German cities, that is to say cities that were part of the German Democratic Republic (GDR). The first reason is simply data availability. For most of the cities concerned there are too many missing observations during the GDR-period. The second and more fundamental reason is that (see Brakman et al., 2004) cities in the GDR were not part of the kind of urban system that lies at the heart of all urban location theories where economic agents are free to choose their location. On the contrary, in the centrally planned economy of the GDR, firms and workers were not free to move between cities. In our view this has the implication that any testing of the stability or any other feature of the pan-German city-size distribution is not very useful during our sample period. Obviously, this does not imply that we are not concerned with the split between West and East Germany or the subsequent reunification, but we will deal with this from the perspective of West-German cities. Finally, 
with respect to the length of the sample period one could argue that it may be worthwhile to include population data for the pre-1925 period as well so as to be able to deal with for instance the WWI shock. For some cities in our sample we have population data that go as far back as 1871, but the number of cities with annual pre-1925 data is rather small so we decided to take 1925 as our cut-off.

\section{Evolution of the city size distribution}

We start our analysis by giving a description of the evolution of the WestGerman urban system. Table 1 below shows that during our sample period total population increased by about $70 \%$ from about 39 million people in 1925 to 67 million in 1999. During the same period the share of urban population declined by about $32 \%$ suggesting a process of suburbanization over the sample period. The average city size in our sample increased by $16 \%$ from 258000 in 1925 to 300000 inhabitants but it seems that the average size has been quite stable from 1955 onwards. Comparing the development of mean city size to that of the median city size, which increased by $42 \%$, the impression comes to the fore that smaller cities grew faster than the larger cities in our sample. This indicates a transition towards a more equal sized city size distribution.

Table 1: Sample descriptives

\begin{tabular}{ccccc} 
year & tot. pop. $(000)$ & \% sample cities & mean city size & median city size \\
\hline 1925 & 39017 & 41.0 & 258329 & 124644 \\
1935 & 41457 & 40.7 & 271881 & 136450 \\
1945 & 46190 & 28.6 & 212859 & 107258 \\
1955 & 52370 & 34.9 & 294494 & 156750 \\
1965 & 59010 & 33.8 & 321229 & 176850 \\
1975 & 61830 & 30.9 & 308143 & 180006 \\
1985 & 60970 & 29.4 & 288691 & 173535 \\
1999 & 66834 & 27.9 & 300295 & 177835 \\
\hline$\Delta_{\prime \prime 25-'} 99$ & $71.3 \%$ & $-32.1 \%$ & $16.3 \%$ & $42.67 \%$
\end{tabular}

The impact of WWII can also be readily seen in the table. While total WestGerman population increased between 1935 and 1945 by about $11 \%$ the average size of the cities in our sample decreased by over $20 \%$, suggesting that the urban population in particular suffered substantial losses during the war.

\subsection{Distribution Characteristics}

Before going into the analys of the evolution of the German city size distribution and in order to fix ideas, Figure 1 below shows the distribution ${ }^{3}$ for both the beginning $(=1925)$ and the end $(=1999)$ of our sample period. Also included in the figure are the city size distributions right at the start of WWII $(=1939)$

\footnotetext{
${ }^{3}$ The distributions are obtained by kernel estimation methods using a Gaussian kernel with the optimal bandwidth chosen using the method proposed in Silverman (1986).
} 
and at the end of war $(=1945)$. In order to control for the changes in mean city size as shown in Table 1, we normalized city sizes for each year by dividing city sizes by the mean city size in the same year.

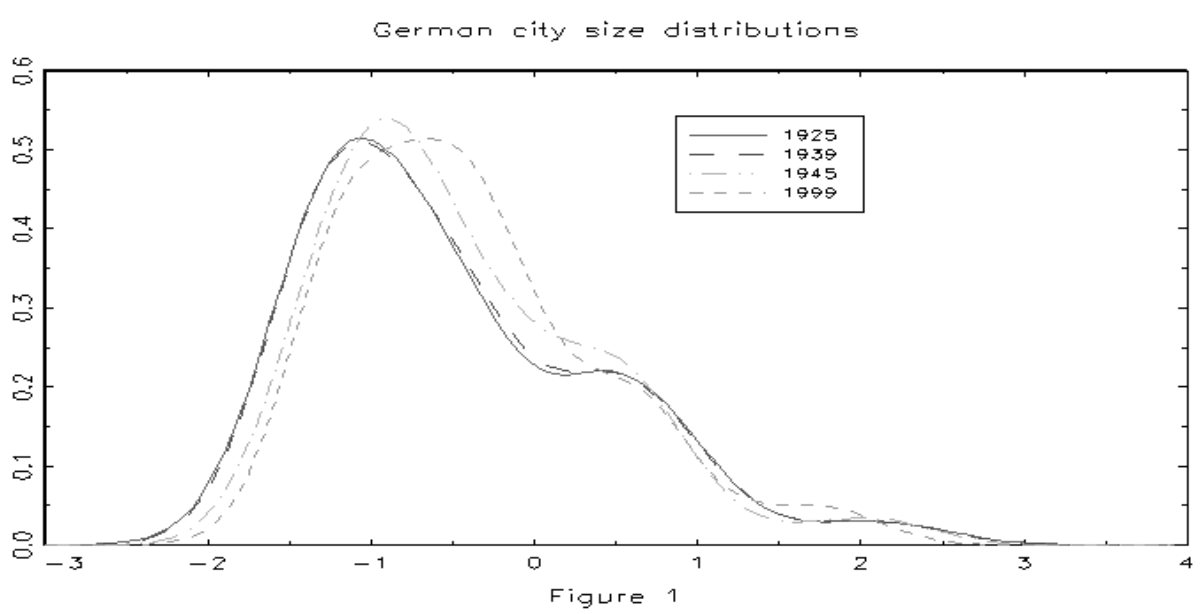

These kernel estimates of the city size distribution already reveal several interesting facts about the evolution of the German urban system. The first observation is that in the pre-WWII period from 1925-1939 the distribution remained remarkably stable, the two distributions overlap almost exactly ${ }^{4}$. The second observation concerns the impact of WWII. The massive loss in urban population suffered during the war (see Table 1) induced a clear shift in the German city size distribution in a period of only six years. Comparing the 1945 distribution with the 1939 distribution, one can see that the main impact of the war is that the city size distribution loses mass in the lower tail and gains substantial mass in the middle. Keeping in mind that we are looking at the distribution of normalized city sizes this movement indicates that during the war the largest cities' population grew slower (or maybe more appropriate, considering the war destruction, declined more) than that of the smaller cities in our sample. Finally, the last interesting point to make about these kernel estimations is that in the period after the war the city size distribution does not go back to its pre-war state ${ }^{5}$, instead the movement that was initiated during the war seems to propagate itself with the distribution gaining even more mass in the middle and losing mass in the lower tail.

To be able to offer a first glance at the dynamics within the distribution over our sample period, Table 2 gives the city that made the largest movement up and the city that made the largest movement down within the city-size distribution, as well as the absolute movement of the average city, and the standard deviation of the average city's (absolute) movement within the city size distribution for the pre-WWII, the WWII, the post-WWII and the total sample period.

The mean and standard deviation of absolute intradistributional city movements

\footnotetext{
${ }^{4}$ Plotting the distributions for the years between 1925 and 1939 confirms this, but these are left out of the figure for sake of clarity.

${ }^{5}$ Again, plotting the distributions for the years between 1945 and 1999 confirms this pattern but are left out of the figure for sake of clarity.
} 
Table 2: Winners, losers and average absolute city movement

\begin{tabular}{l|llll} 
& pre-WWII & WWII & post-WWII & $1925-1999$ \\
\hline $\max (-)$ & -5 (Pforzheim) & -17 (Würzburg) & -21 (Flensburg) & -15 (Wannne-Eickel) \\
$\max (+)$ & 5 (o.a Stuttgart) & 21 (Flensburg) & 19 (Münster) & 18 (Oldenburg) \\
mean & 1.7 & 4.7 & 3.7 & 4.0 \\
s.d. & 1.6 & 5.5 & 4.4 & 3.9
\end{tabular}

is considerably lower before WWII than during and after the war conveying the same message of a major impact of the war on the urban landscape in Germany. Also the magnitude of the change in rank of the winner and the loser increases considerably during and after the war. Over the whole sample period the average city moves four places up or down in the city size distribution. Taken together, Table 2 and Figure 1 suggest that both the movement of the distribution as a whole as well as the relative position of cities within this distribution are of importance.

\subsection{Distribution dynamics}

To take a better look at the distributional dynamics suggested by Figure 1 and Table 2, we now turn to the estimation of the movement of the city size distribution over the sample period. In order to do that we use Markov chain techniques following Black and Henderson (2003) and Eaton and Eckstein (1997) who also look at the distributional dynamics of urban systems using Markov techniques. These techniques allow one to quantify the dynamics of the distribution as a whole based on the intradistributional dynamics of the individual cities that make up this city size distribution.

The use of Markov chain techniques requires the quantification of the distribution by discretizing it. One has to assign each city to one of a predetermined number of groups based on its relative size. Letting $f_{t}$ denote the vector of the resulting discretized distribution at period $t$ and assuming that the distribution follows a homogenous, stationary, first order Markov process, the distributional dynamics can be characterized by the following Markov chain,

$$
f_{t+x}=M f_{t}
$$

where $\mathrm{M}$ is the so-called $\mathrm{x}$-period transition matrix that maps the distribution at period $\mathrm{t}$ into period $\mathrm{t}+\mathrm{x}$. Each element, $m_{i j}$, in the transition matrix gives the probability of a city being allocated in group $\mathrm{j}$ of the distribution in period $\mathrm{t}+\mathrm{x}$ given its position, $\mathrm{i}$, in period $\mathrm{t}$. As the estimation of this transition matrix requires the discretization of the city size distribution into discrete groups, we chose to allocate each city to one of five groups based on its relative size.. This requires the definition of the cut-off points that determine which city belongs to which group. Following Eaton and Eckstein (1997) and Quah (1993), we choose cut-off points exogenously and at city sizes of $\frac{1}{4}, \frac{1}{2}, 1$ and 2 times the average city size, $\mu$, for a given year. Table 3 shows the resulting discretized distributions for the same years as for which Figure 1 shows the kernel estimates of the entire city empirical size distributions. 
Table 3: Discretized city size distributions

\begin{tabular}{l|cccc} 
city size (c) & 1925 & 1939 & 1945 & 1999 \\
\hline 1) $c<\frac{1}{4} \mu$ & 0.129 & 0.129 & 0.065 & 0.016 \\
2) $\frac{1}{4} \mu<c<\frac{1}{2} \mu$ & 0.387 & 0.355 & 0.435 & 0.371 \\
3) $\frac{1}{2} \mu<c<\mu$ & 0.210 & 0.242 & 0.226 & 0.355 \\
4) $\mu<c<2 \mu$ & 0.161 & 0.193 & 0.177 & 0.177 \\
5) $2 \mu<c$ & 0.113 & 0.081 & 0.097 & 0.081
\end{tabular}

Note: The numbers in the Table indicate the share of cities that fall in a particular category in a particular year. For example in 1925, 13\% of the cities fell in the smallest category.

Even though the distributions are substantially simplified by the discretization, the afore mentioned pattern of stability before WWII and a shift towards the middle of the distribution during the war shows up in the table ${ }^{6}$.

Having discretized the distribution into these five discrete groups, we can now turn to the estimation of the transition matrix, M. As we have yearly population data we choose to estimate the 1 year $(x=1)$ transition matrix. Each transition probability, $m_{i j}$, in the transition matrix $\mathrm{M}$ is estimated by maximum likelihood, i.e.

$$
\hat{m}_{i j}=\frac{\sum_{t=1}^{T-1} n_{i t, j t+1}}{\sum_{t=1}^{T-1} n_{i t}}
$$

where $n_{i t, j t+1}$ denotes the number of cities moving from group $i$ in year $t$ to group $j$ in year $t+1$, and $n_{i t}$ the number of cities in group $i$ in year $t$.

Table 4: Pre WWII 1-yr transition matrix

\begin{tabular}{|c|c|c|c|c|c|c|}
\hline & \multicolumn{5}{|c|}{$\mathrm{t}+1$} \\
\hline & & 1 & 2 & 3 & 4 & 5 \\
\hline & 1 & $\begin{array}{c}0.983 \\
(0.012)\end{array}$ & $\begin{array}{c}0.017 \\
(0.012)\end{array}$ & 0 & 0 & 0 \\
\hline & 2 & $\begin{array}{c}0.006 \\
(0.004)\end{array}$ & $\begin{array}{c}0.988 \\
(0.006)\end{array}$ & $\begin{array}{c}0.006 \\
(0.004)\end{array}$ & 0 & 0 \\
\hline $\mathrm{t}$ & 3 & 0 & 0 & $\begin{array}{c}0.995 \\
(0.005)\end{array}$ & $\begin{array}{c}0.005 \\
(0.005)\end{array}$ & 0 \\
\hline & 4 & 0 & 0 & $\begin{array}{c}0.007 \\
(0.007)\end{array}$ & $\begin{array}{c}0.986 \\
(0.009)\end{array}$ & $\begin{array}{c}0.007 \\
(0.007)\end{array}$ \\
\hline & 5 & 0 & 0 & 0 & $\begin{array}{c}0.034 \\
(0.019)\end{array}$ & $\begin{array}{c}0.966 \\
(0.019)\end{array}$ \\
\hline
\end{tabular}

Notes: standard errors, $\sqrt{\frac{\hat{m}_{i j}\left(1-\hat{m}_{i j}\right)}{N_{i}}}$ with $N_{i}=\sum_{t=1}^{T-1} n_{i t}$, between brackets. $1,2, \ldots, 5$ correspond to the different groups of the discretized distribution as in Table 3.

${ }^{6}$ Although quantitatively the results are sensitive to the choice of cut-off points this has no effect on the qualitative outcomes of our analysis. 
Table 5: WWII transition matrix

\begin{tabular}{|c|c|c|c|c|c|c|}
\hline & \multicolumn{5}{|c|}{1945} \\
\hline & & 1 & 2 & 3 & 4 & 5 \\
\hline \multirow{9}{*}{1939} & 1 & $\begin{array}{c}0.250 \\
(0.153)\end{array}$ & $\begin{array}{c}0.750 \\
(0.153)\end{array}$ & 0 & 0 & 0 \\
\hline & \multirow[t]{2}{*}{2} & 0.091 & 0.818 & 0.091 & 0 & 0 \\
\hline & & $(0.061)$ & $(0.082)$ & $(0.061)$ & & \\
\hline & \multirow[t]{2}{*}{3} & \multirow[t]{2}{*}{0} & 0.200 & 0.733 & 0.067 & 0 \\
\hline & & & $(0.103)$ & $(0.114)$ & $(0.064)$ & \\
\hline & \multirow[t]{2}{*}{4} & \multirow[t]{2}{*}{0} & \multirow[t]{2}{*}{0} & 0.083 & 0.833 & 0.083 \\
\hline & & & & $(0.080)$ & $(0.108)$ & $(0.080)$ \\
\hline & \multirow[t]{2}{*}{5} & \multirow[t]{2}{*}{0} & \multirow[t]{2}{*}{0} & \multirow[t]{2}{*}{0} & \multirow[t]{2}{*}{0} & 1 \\
\hline & & & & & & $(0)$ \\
\hline
\end{tabular}

Notes: standard errors, $\sqrt{\frac{\hat{m}_{i j}\left(1-\hat{m}_{i j}\right)}{N_{i}}}$ with $N_{i}=\sum_{t=1}^{T-1} n_{i t}$, between brackets. $1,2, \ldots, 5$ correspond to the different groups of the discretized distribution as in Table 3.

Table 6: post WWII 1-yr transition matrix

\begin{tabular}{|c|c|c|c|c|c|c|}
\hline & & \multicolumn{5}{|c|}{$\mathrm{t}+1$} \\
\hline & & 1 & 2 & 3 & 4 & 5 \\
\hline & 1 & $\begin{array}{c}0.933 \\
(0.024)\end{array}$ & $\begin{array}{c}0.067 \\
(0.024)\end{array}$ & 0 & 0 & 0 \\
\hline & 2 & $\begin{array}{c}0.003 \\
(0.001)\end{array}$ & $\begin{array}{c}0.989 \\
(0.003)\end{array}$ & $\begin{array}{c}0.008 \\
(0.002)\end{array}$ & 0 & 0 \\
\hline $\mathrm{t}$ & 3 & 0 & $\begin{array}{c}0.004 \\
(0.002)\end{array}$ & $\begin{array}{c}0.994 \\
(0.002)\end{array}$ & $\begin{array}{c}0.002 \\
(0.001)\end{array}$ & 0 \\
\hline & 4 & 0 & 0 & $\begin{array}{c}0.006 \\
(0.003)\end{array}$ & $\begin{array}{c}0.982 \\
(0.006)\end{array}$ & $\begin{array}{c}0.012 \\
(0.005)\end{array}$ \\
\hline & 5 & 0 & 0 & 0 & $\begin{array}{c}0.018 \\
(0.007)\end{array}$ & $\begin{array}{c}0.982 \\
(0.007)\end{array}$ \\
\hline
\end{tabular}

Notes: standard errors, $\sqrt{\frac{\hat{m}_{i j}\left(1-\hat{m}_{i j}\right)}{N_{i}}}$ with $N_{i}=\sum_{t=1}^{T-1} n_{i t}$, between brackets. $1,2, \ldots, 5$ correspond to the different groups of the discretized distribution as in Table 3.

Using this estimation technique we estimate the 1-year transition matrix for the pre-WWII period, the 6-year transition matrix during WWII (1939-1945) and the 1-year transition matrix for the post-WWII period. Tables 4-6 show the corresponding estimates of these matrices. The diagonal elements of the 1-year transition matrices before (Table 4) and after (Table 6) the war are close to one, which indicates that the city size distribution does not change dramatically over a period of one year. It is very interesting to note however that where before WWII all off-diagonal elements are not significantly different from zero this changes after WWII when almost all off-diagonal elements are significantly different from zero. This significant off-diagonal movement indicates less stability of the distribution after the war, which complies to the visual inspection 
of Figure 1. The magnitude and direction of this significant movement after the war can also be inferred when looking at the difference between the upper and lower off-diagonal entries of the transition matrix. This shows that most movement occurs from the smallest cities towards the middle of the distribution and, be it a lot smaller in magnitude, from the largest cities towards the middle. This movement can be seen as evidence of a tendency of the distribution to gain mass in the middle indicating a city size distribution with more cities of medium size.

Next we turn to the impact of WWII on the German city size distribution. Table 1 already showed that the German urban population suffered a substantial loss during the war with a decrease of more than $10 \%$. In turn the transition matrix in Table 5 shows the effect of this loss of urban population on the distribution in our sample. The most striking result that comes from estimating this WWII transition matrix is that $75 \%$ of the cities in the smallest category in 1939 made the transition to the 2 nd to smallest category during the war period, indicating that the smallest cities suffered substantially less than the average city during the war. Second in magnitude is the finding that $20 \%$ of the cities in the middle category moved one category down to the 2nd to smallest group, indicating that small-medium sized cities suffered quite substantial losses during the war. Not a single city in the highest category shifts to a lower category due to the destruction during the war, this however does not indicate that these cities were not hit very hard during the war, it merely reflects the fact that these cities were very large before the war and the substantial loss of population during the war was not large enough to make them shift to a lower category in the discretized distribution.

Besides the fact that the transition matrices themselves are of interest, one can also use them to do some interesting thought experiments (see also Black and Henderson, 2003 and Eaton and Eckstein, 1997). Using our estimated pre- and post-WWII transition matrices we ask ourselves the following questions:

1. Assuming WWII would not have happened and the transition matrix remained as in the pre-WWII period, what would the city size distribution have looked like in 1945 and 1999?

2. Assuming that the estimated transition matrix remained as during the pre-WWII (post-WWII) period, would the city size distribution converge and if so what would it look like in the limit?

We will answer each of these questions consecutively. First however we check the predictive power of the estimated transition matrices. To do this we use the estimated transition matrices in Table 4 and 6 and the observed distribution in 1925 and 1945 of Table 3 respectively and calculate the predicted distribution in 1939 and 1999. This can be done by using the following formula,

$$
\hat{f}_{t+x}=M^{x} f_{t}
$$

where $\hat{f}_{t+x}$ is the distribution $x$ years from the observed distribution in year t and $M^{x}$ is the transition matrix $M$ multiplied $x$ times by itself, e.g. $M^{2}=$ $M \times M$. Column 1 and column 5 of Table 7 below give the resulting predicted 
distributions for 1939 and 1999 respectively. Comparing these two to the actual observed distributions in Table 3 shows that the estimated transition matrices are able to predict the two actual distributions quite accurately, giving confidence in our estimated transition matrices.

Table 7: Predicted city size distributions

\begin{tabular}{c|cccccc} 
city size $(\mathrm{S})$ & 1939 & 1945 & 1999 & limit & 1999 & limit \\
\hline transition matrix & $M_{\text {pre }}$ & $M_{\text {pre }}$ & $M_{\text {pre }}$ & $M_{\text {pre }}$ & $M_{\text {post }}$ & $M_{\text {post }}$ \\
observed distribution & $f_{1925}$ & $f_{1925}$ & $f_{1925}$ & nvt & $f_{1945}$ & nvt \\
\hline 1 & 0.130 & 0.130 & 0.115 & 0 & 0.018 & 0.010 \\
2 & 0.354 & 0.341 & 0.257 & 0 & 0.367 & 0.237 \\
3 & 0.242 & 0.255 & 0.347 & 0.515 & 0.361 & 0.485 \\
4 & 0.191 & 0.199 & 0.232 & 0.404 & 0.151 & 0.160 \\
5 & 0.083 & 0.075 & 0.049 & 0.081 & 0.103 & 0.108
\end{tabular}

Notes: $M_{\text {pre }}, M_{\text {post }}$ denote the estimated 1-yr transition matrix for the pre- and post-WWII period transition matrix (see Table 3 and 5) respectively. 1,2, ., 5 correspond to the different groups of the discretized distribution as in Table 3.

Next turning to our two thought experiments, we answer the first question using equation (3). Pretending that WWII never happened, we can estimate the distribution in 1945 and 1999 using the actual observed distribution in 1925, the estimated pre-WWII transition matrix and taking $\mathrm{x}=20,74$ respectively. The resulting predicted distributions are in column 2 and 3 of Table 7. Comparing these two with the actual observed distributions for these years in Table 3, we see that for 1945 the main difference between the predicted -as if WWII did not happen- distribution and the actual distribution is found in the smallest two groups, the smallest group being predicted much too large, about $200 \%$ as large as observed and the second-smallest group predicted much too small about $25 \%$ that of which observed. Comparing the actual and predicted -as if WWII did not happen- distribution for 1999, one sees a continuation of this pattern with the smallest group being predicted 10 times as large as observed and the secondsmallest group predicted at about two thirds the actual size. This confirms the notion that during WWII the smallest cities in the distribution grew faster or better suffered a lower loss of population than the average German city, with a continuation of this pattern after the war.

The same conclusion can be drawn from our second thought experiment. This question asks what would happen to the city size distribution if it continued to evolve as estimated by either the 1-yr pre-WWII or 1-yr post-WWII transition matrix. If one is willing to assume this, these limiting distributions are shown in column 4 for the pre-WWII and in column 6 of Table 7 for the post-WWII case $^{7}$. The pre-WWII limiting distribution is not that informative because it assigns zero mass to the two smallest groups, which is due to the the fact that the transition matrix gives zero probability for a city in one of the three highest categories to make the transition to one of the two smallest categories. As cities

\footnotetext{
${ }^{7}$ These limiting distributions corresponds to the (normalized) eigenvector of the respective transition matrix associated with the eigenvalue equal to one. The condition for the limiting distribution to exist is for the second largest eigenvalue to be smaller than one, which holds in our case.
} 
in the two smallest groups do eventually transfer to the higher categories this will in the limit result in an emptying of these two categories. However it suggests a movement towards a city size distribution characterized by medium-large cities. The limiting distribution based on the transition matrix after the war gives a completely different picture, namely that of a city size distribution characterized by small-medium sized cities, i.e. a more equal spreading of population over the urban landscape.

The overall impression from the above analysis of both the intradistributional and distributional dynamics of the German city size distribution is that the impact of WWII did have a substantial direct and lasting effect on the German urban landscape. In the introduction of our paper we stated that theories on urban growth can be distinguished according to their prediction regarding the stability of the city-size distribution to shocks. Based on the evidence presented in this section our conclusion is that the German (i.e. West-German) city-size distribution during the period 1925-1999 has been sensitive to the WWII shock ${ }^{8}$ both in terms of the city size distribution as a whole as the relative position of cities within the distribution. So far our analysis has been largely descriptive, in the next two sections we therefore turn from describing the evolution of the city size distribution to providing proper empirical tests that allow us to distinguish more properly between the three competing theories mentioned in the introduction.

\section{Zipf's Law and Gibrat's Law}

As mentioned in the introduction, the notion of a power law distribution describing the upper tail of city size distribution goes at least back as far as 1913 when the German geographer Auerbach (1913) noted this to be the case for Germany. The empirical literature has mainly focused on a special case of such a power law, namely that of city sizes in the upper tail of the distribution being distributed Pareto with coefficient $a=1^{9}$. This empirical regularity is better known as Zipf's law and has been found to hold approximately for many countries over several years (see e.g. Soo, 2005 and Nitsch, 2005) ${ }^{10}$ The studies that test for Zipf's Law mainly do so by means of a Zipf regression, that is regressing the $\log$ of cities' rank $r$ within the distribution on the log of city sizes. If city sizes are indeed distributed according to a power law it can be easily shown (see e.g. Eeckhout, 2004) that the rank of a particular city in this distribution is given by:

$$
r=\tilde{N}\left(\frac{\tilde{S}}{S}\right)^{a}
$$

\footnotetext{
${ }^{8}$ Which is consisent with the findings in Brakman et al (2004) and Bosker et al (2005), see also section 5 below.

${ }^{9}$ Formally a variable (in our case city size), S, adhering to a power law is distributed according to a Pareto distribution if the density function of this variable satisfies, $p(S)=$ $\frac{a \tilde{S}^{a}}{S^{a+1}} \quad \forall S \geq \tilde{S}$

${ }^{{ }^{a}}$ Approximately is the key word here, see Brakman, Garretsen and van Marrewijk (2001), ch. 7 or Gabaix and Ioannides (2004) for evidence that the Zipf coefficient is sometimes significantly different from 1 and/or changing over time.
} 
where $S$ is the size of the city, $\tilde{S}$ is a (arbitrary) minimum city size, and $\tilde{N}$ the number of cities above this truncation point. Testing for Zipf's law can now be done by a regression of $\ln (r)$ on $\ln (S)$ in order to estimate the so-called Zipf coefficient, i.e. rewriting (4) in logs gives:

$$
\ln (r)=\alpha-a \ln S
$$

where $\alpha=\ln (\tilde{N})+a \ln (\tilde{S})$ is a constant. If it cannot be rejected that the estimated $\hat{a}$ equals 1 this constitutes evidence in favor of Zipf's Law. By adding a random error term to (5) we estimated the following equation by Ordinary Least Squares ${ }^{11}$ for all years in our sample:

$$
\ln (r)=\alpha+a \ln (S)+\epsilon
$$

Figure 2 below shows the results of this regression for each of the years in our sample.

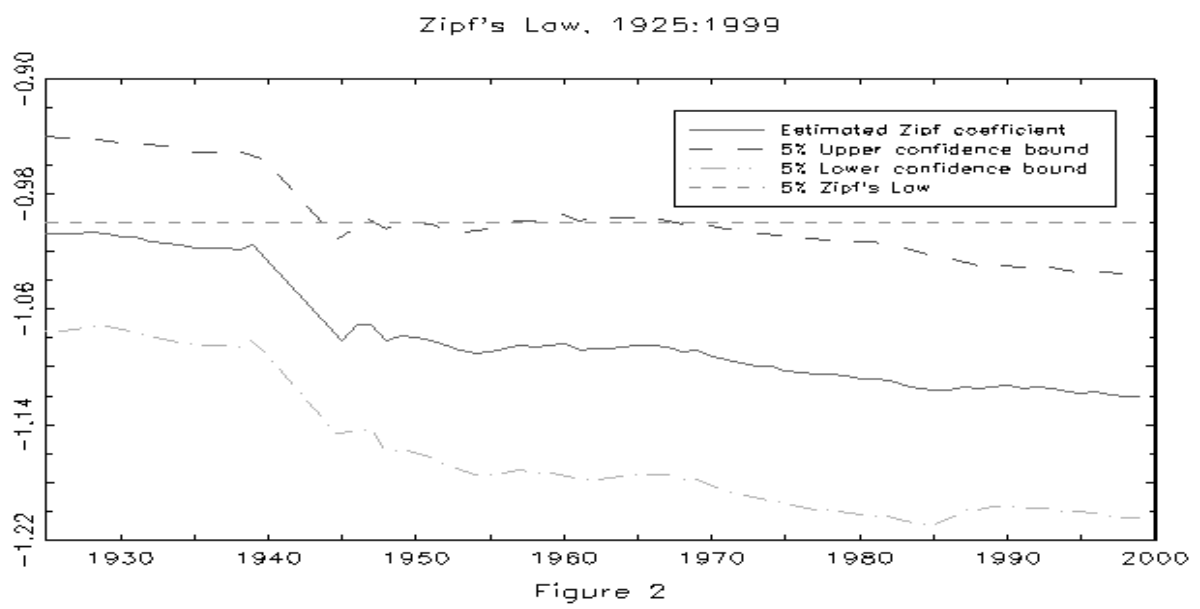

The figure shows both the OLS estimate of $a$ and the 5\% upper and lower confidence bands $\left(a \pm 2 \sigma_{a}\right)$ corresponding to the estimated OLS standard error of $a, \sigma_{a}$. Figure 2 shows that during the pre-WWII period the point estimate of $a$ is very close to -1 and not significantly different from -1 . The impact of WWII also shows when looking at the Zipf-regression results. The estimated Zipf coefficient, $a$, drops from almost -1 to about -1.08 right after the war, again confirming the notion of a more equal spread of urban population over the WestGerman cities in our sample due to the relative lower loss of urban population of smaller cities during WWII. In the post-WWII period the point estimate shows

\footnotetext{
${ }^{11}$ As pointed out by Gabaix and Ioannides (2004) there do exist some pitfalls when estimating a Zipf regression by OLS. The magnitude of $a$ is typically underestimated, but more severely the standard errors of the estimated $a$ are also underestimated leading to an overrejection of Zipf's Law. We keep to OLS noting that using the approximate standard errors as suggested by Gabaix and Ioannides (2004) indeed does not result in a rejection of Zipf's Law. We also considered using the Hill estimator, however as noted in Embrechts et al. (1997) the small sample properties of this estimator are rather bad and we therefore decided not to use it for our sample of 62 cities.
} 
no return to -1 , instead it steadily decreases, becoming consequently significantly different from -1 at a $5 \%$ level from about 1970 onwards and finally reaching a point estimate of -1.12 in 1999 (see Soo, 2005, for similar evidence for other countries). Regarding the adherence of the city size distribution to Zipf's Law, the results are consistent with the idea that WWII has had a major impact, shocking the city size distribution from Zipf's Law to one characterized by a more equal spread of urban population over the different cities. This immediate impact of the war is not reversed in the post-WWII period but the distribution moves to one characterized by an even more equal spread of urban population, with the estimated Zipf coefficient significantly different from -1 . This confirms our earlier findings in the previous section based on the Markov chain analysis. Note however that this tendency to a more equal spreading of urban population in the post-WWII period is also found for other developed countries indicating that in case of Germany WWII is probably not the only relevant shock or change that hit the city-size distribution in this period.

However, as noted above, performing a Zipf regression using OLS may not be the ideal way to test for Zipf's Law as it is subject to some criticism. The next sub-section therefore adopts a different technique to verify the existence of Zipf's Law for our German sample. This approach is based upon the behavior of individual cities in our sample.

\subsection{Individual city size evolution and Gibrat's law}

Gabaix (1999) and subsequently Córdoba (2004) and Eeckhout (2004) opened up an alternative way to empirically verify the relevance of Zipf's Law for a particular city size distribution. Gabaix (1999) shows that if individual city size growth adheres to Gibrat's Law for means and variances, that is to say if city sizes grow randomly with the same expected growth rate and the same variance independent of city size, the city size distribution converges to one adhering to Zipf's law in the upper tail. The contribution of Córdoba, 2004 is that Gibrat's Law is not only a sufficient condition, but a necessary condition for Zipf's Law to hold. So, another way of testing for Zipf's Law is to show that individual city sizes adhere to Gibrat's Law. The next sections look for empirical evidence on Gibrat's Law using both nonparametric and parametric techniques.

\subsubsection{Nonparametric evidence on Gibrat's Law}

Ioannides and Overman (2003) and Eeckhout (2004) resort to nonparametric multivariate kernel estimations to shed empirical light on the relevance Gibrat's Law. Both papers find considerable evidence in favor of Gibrat's Law for the case of the US urban system. Following this methodology, we plot the distribution of five-year city size growth rates conditional on initial city size for the total, pre-WWII, post-WWII and WWII period along with the corresponding contour plots $^{12}$. The results are shown in Figure 3a-3d below. By taking any point, say

\footnotetext{
${ }^{12}$ The stochastic kernels are estimated non-parametrically using a Gaussian kernel and with the bandwith chosen following Silverman (1986). The contour plots can be read in the same way as standard topographical height maps with the lines in the plots connecting points on the distribution of similar height.
} 
$\mathrm{S}$, on the city size axis and taking the cross-section through the kernel estimate parallel to the city size growth rate axis, one obtains the distribution of five year growth rates conditional on the initial city size being S.
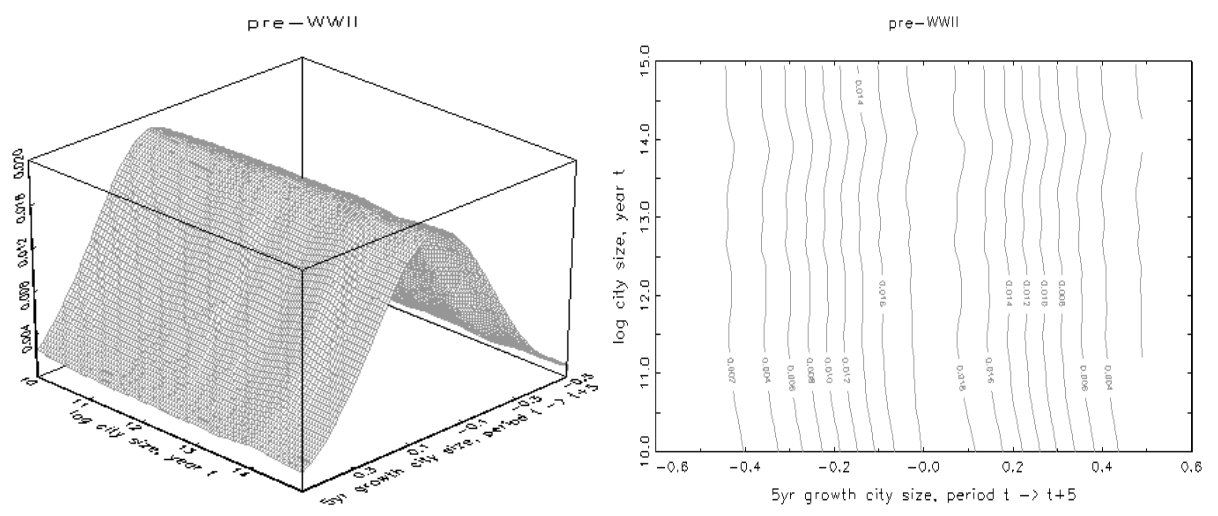

Figure 3a: Pre-WWII stochastic kernel estimate: $\log$ city size to 5yr city growth
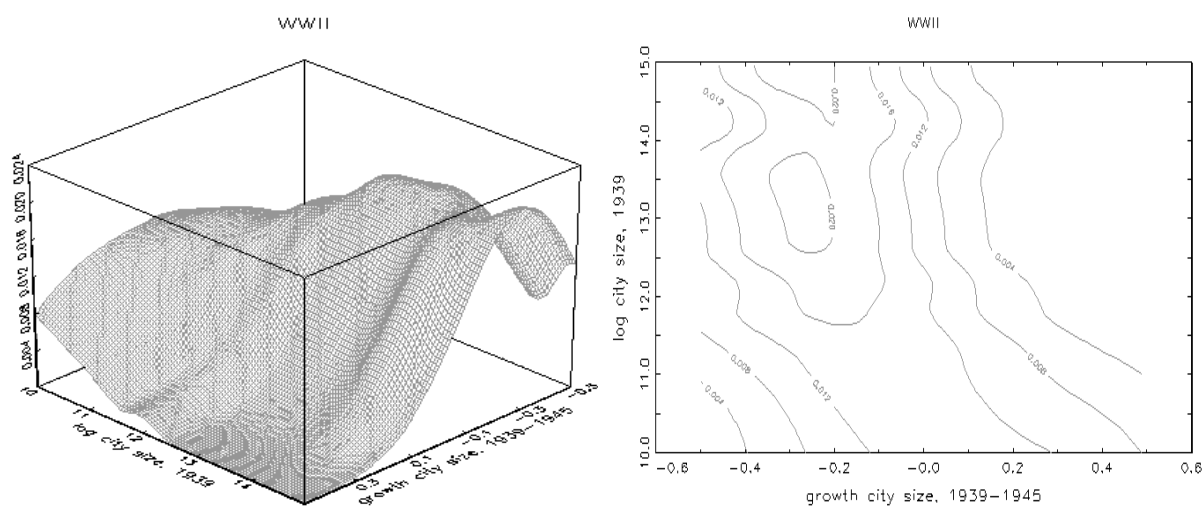

Figure 3b: WWII stochastic kernel estimate: $\log$ city size 1939 to city growth during WWII
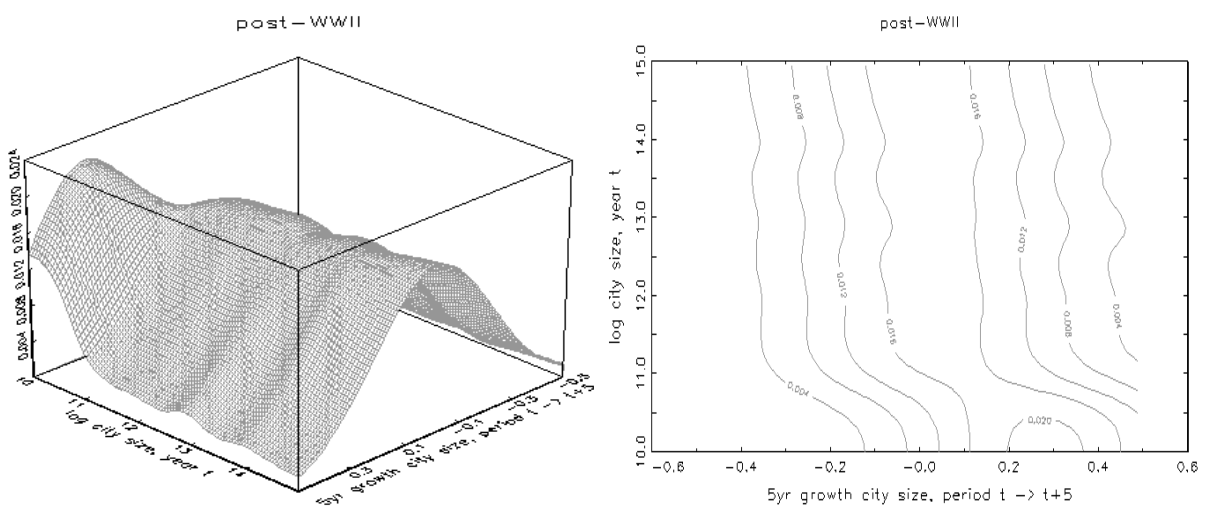

Figure 3c: Post-WWII stochastic kernel estimate: $\log$ city size to 5yr city growth 

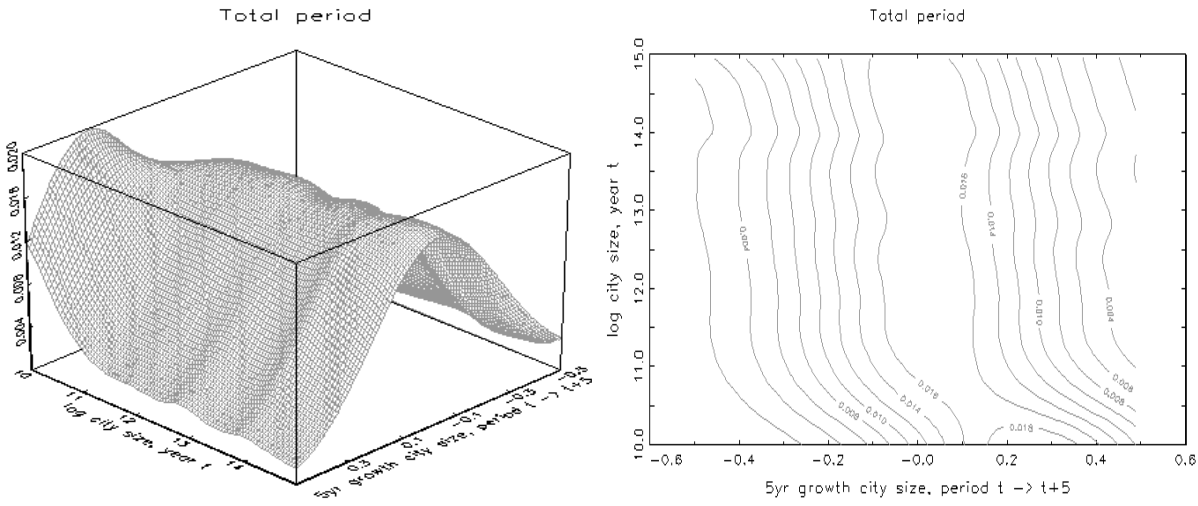

Figure 3d: Stochastic kernel estimate 1925-1999: log city size to 5yr city growth

The plotted kernel in Figure 3a shows that before WWII, German city size growth behaved remarkably well according to Gibrat's Law. The estimated kernel and corresponding contour plot show no significant difference in the conditional growth rate distribution for cities of different size. This provides compelling evidence that the growth rate of the cities in our sample in the pre-WWII period were not dependent on the initial size of the city. It is interesting to relate these results to our estimated Zipf regression. The fact that before the war individual city growth seems to adhere quite well to Gibrat's Law shows itself very clearly in the finding of a Zipf-coefficient very close to -1 . After WWII, the evidence from the estimated stochastic kernel and contour plot in Figure $3 \mathrm{c}$ show a completely different picture. For the largest cities in our sample city growth rates seem to still be largely independent of initial city size. This does not hold true for the smaller cities in our sample however. Figure $3 \mathrm{c}$ shows clear evidence of the smaller cities in our sample growing on average much faster than the larger ones. This shift in the mean of the conditional distribution for smaller cities is maybe most clearly seen from the contour plot which makes a significant shift to the right for the smallest cities. The evidence for Gibrat's Law is thus much more meagre for the post-WWII period, reflecting itself in the lower Zipf-coefficient in Figure 2.

Before turning to the overall picture of individual German city growth over the whole sample period from 1925-1999, we turn to the immediate impact of WWII on German city sizes. As can be seen in Figure 3b, the largest cities suffered more heavily during the 6 year period of WWII. Smaller cities suffered less on average but the variance of city growth during the war increases also substantially for the smaller cities in the sample. This suggests that larger cities were not only damaged more heavily, the destruction of these larger cities was also less variable across cities of similar size. That is larger cities were all hit quite similarly and more heavily compared to the smaller cities in our sample (which may be evidence on the success of the Area Bombing-tactics of Allied Bomber Command aimed at the urban population in Germany, see Brakman et al, 2004).

Combining Figures 3a-3c, the estimated stochastic kernel for the whole sample period in Figure 3d does not seem to provide very clear evidence that Gibrat's 
Law holds. The effect of the lesser destruction of smaller cities during WWII and the higher growth rates of these same smaller cities after the war dominates the equal growth rates before the war, resulting in the overall picture showing a similar (be it somewhat smaller) shift in the conditional growth rate distribution for the smaller cities in the sample as for the post-WWII case. This result of a size dependent mean growth rate, and a more or less initial size independent variance contrasts to empirical studies done using US city size data. Both Eeckhout (2004) and Ioannides and Overman (2003) find evidence for the USA of a more or less size independent mean growth rate and an increasing variance for smaller cities, which can be reconciled with the decreasing Zipf coefficient they find for the USA. The explanation of the lower Zipf coefficient found in our sample over the post-WWII period seems to be a more equal spreading of urban population over the cities in Germany and not so much an increased variance of city size for smaller cities.

\section{Unit root testing and parametric evidence on Gibrat's Law}

The nonparametric kernel estimates of the previous section remain largely based on pooled panel-data evidence. In order to fully exploit the unique time series dimension of our data set, we now turn to a, more dynamic way of testing for Gibrat's Law. Given the many observations over time in our data set, we follow the suggestion made by Gabaix and Ioannides (2004) who state: "Hence one can imagine that the next generation of city size evolution empirics could draw from the sophisticated econometric literature on unit roots" (Gabaix and Ioannides, 2004, pp. 20).

Clark and Stabler (1991) were one of the first to notice that Gibrat's Law can be tested for using unit root tests. Following their exposition of the relationship between Gibrat's Law and unit root testing, assume that the size of city i at time $t$, can be related to the size of that same city at time $t-1$ according to the following formula:

$$
S_{i t}=\gamma_{i t} S_{i t-1}
$$

Thus $\gamma_{i t}$ denotes the growth rate of city i over the period t- 1 to $t$. Next assume that this growth rate can be decomposed into three components, a random component $\epsilon_{i t}$, a non-stochastic component relating the current growth rate to a (possibly time-varying) constant and past growth rates and initial city size:

$$
\gamma_{i t}=K_{i t} S_{i t-1}^{\delta_{i}} \prod_{j=1}^{p} \gamma_{i t-j}^{\beta_{i j}}\left(1+\epsilon_{i t}\right)
$$

where $K_{i t}$ is a possibly time-varying constant, and $\delta_{i}$ and $\beta_{i j}$ are parameters measuring the relative importance of initial city size and past growth rates on current city growth respectively and $\epsilon_{i t}$ is a random error term. Now Gibrat's Law would require $\delta_{i}=0$, such that initial city size does not influence the growth of a particular city. In order to be able to test for this, substitute equation (8) 
into (7), take logs and subtract $\ln S_{t-1}$ from both sides of the equation to obtain the following estimatable equation:

$$
\Delta \ln S_{i t}=c_{i t}+\rho_{i} \ln S_{t-1}+\sum_{j=1}^{p} \beta_{i j} \Delta \ln S_{t-j}+\epsilon_{i t}
$$

where $c_{i t}=\ln K_{i t}, \rho_{i}=\left(\delta_{i}-1\right)$ and the following approximate equality is used: $\ln \left(1+\epsilon_{i t}\right) \simeq \epsilon_{i t}$ for small values of $\epsilon_{i t}$. This shows immediately that testing for Gibrat's Law amounts to testing for a unit root in city sizes. If we find that $\rho_{i}$ is not significantly different from zero, i.e. a unit root in city size, this constitutes evidence in favor of city i's growth rate being independent of city $i$ 's size. On the other hand an estimated $\rho_{i}$ smaller than zero would indicate that the evolution of city $i$ is a stationary process implying that city $i$ 's growth rate declines with initial city size.

There are to date very few studies that actually perform unit root tests on individual city sizes to test for the relevance of Gibrat's Law. Notable exceptios are Clark and Stabler (1991) and Black and Henderson (2003). Clark and Stabler (1991) conclude in favor of the relevance of Gibrat's Law based on the evolution of the city sizes of the seven largest Canadian cities over the period 1975-1984. As the ADF unit root tests are infamous for their small sample properties, a sample period of only 10 years seems to put a substantial doubt on their results ${ }^{13}$. Black and Henderson (2003) find no evidence for Gibrat's Law using data on the US metropolitan areas when testing for a unit root in city sizes. As Clark and Stabler (1991) they also have only 10 observations over time (decade-by-decade city sizes over a total period of 90 years). They take explicit note of the hereby potentially induced small-sample problem and resort to a recently proposed panel unit root test, i.e. Levin-Lin-Chu (2002). Given their very large cross-section dimension, the use of this panel technique is likely to solve the problems associated with the small sample bias. However as noted by Gabaix and Ioannides (2004), their test does not correct for the potential autocorrelation in the residuals, which can severely bias the results regarding the unit root hypothesis and thus regarding the relevance of Gibrat's Law. Furthermore they do not control for cross-sectional dependence across the cities in the panel, which sheds further econometric doubt on the robustness of their results.

Given our substantial number of observations over time, i.e. annual population data for the period 1925-1999 (except for 5 years during the WWII period, 19401944), we argue that we can use standard unit root tests on individual city sizes. Given the decline of total urban population over the sample period we decided to allow the constant term in the growth rate, $K_{i t}$, to be possibly trend-wise changing over time ${ }^{14}$, i.e. $K_{i t}=K_{i} t$ resulting in the following equation that will be estimated for each city separately:

\footnotetext{
${ }^{13}$ The authors note this problem and propose the estimation of a restricted SUR model to overcome this problem, however the distributional properties of this SUR estimator are not known and given the small number of cities this is unlikely to solve the potential small sample bias.

${ }^{14}$ Black and Henderson (2003) also include a deterministic trend in their estimated equation.
} 


$$
\Delta \ln S_{t}=c+\zeta t+\rho \ln S_{t-1}+\sum_{j=1}^{p} \beta_{i j} \Delta \ln S_{t-j}+\epsilon_{t}
$$

The first column in Table 8 shows the result of these city specific unit root tests. It shows the percentage of cities for which the null of a unit root is not rejected at a $1 \%, 5 \%$ and $10 \%$ level. For completeness, it also gives the outcome of two different panel unit root tests. The first is the earlier mentioned Levin-Lin-Chu (2002) test, which tests the null of all series having a unit root versus the alternative of all series being stationary with the same autoregressive parameter. The second is the later developed Im-Pesaran-Shin (2003) test that tests the null of a unit root in all series versus the alternative of some of the series being stationary (with a potentially varying autoregressive parameter). Hereby the latter test is thus somewhat less restrictive under the alternative, allowing different cities to converge to their stationary growth path at different rates under the alternative hypothesis.

Table 8: Results unit root tests on city sizes

$$
\text { a: City specific tests }
$$

\begin{tabular}{ccc} 
alternative hypothesis: & trend stationary & trend stationary with break \\
\hline significance level & \%unit root rejected & \%unit root rejected \\
$1 \%$ & $0 \%$ & $59.1 \%$ \\
$5 \%$ & $0 \%$ & $74.2 \%$ \\
$10 \%$ & $0 \%$ & $75.8 \%$ \\
\hline
\end{tabular}

b: Panel tests

\begin{tabular}{lcc} 
& test-statistic (p-value) & test-statistic \\
\hline Levin-Lin-Chu & $0.543(0.706)$ & \\
Im-Pesaran-Shin & $-2.061(0.020)$ &
\end{tabular}

Notes: The null hypothesis is in all cases a unit root in city size. Following the suggestion in $\mathrm{Ng}$ and Perron (1995) we choose the optimal number of lagged growth rates to be included in the regression to control for autocorrelation using a 'general-to-specific procedure' based on the t-statistic. The maximum lag length to start off this procedure is set at 11. The panel test statistics are the $t^{*}$ and the $\bar{Z}$ statistic in case of the Levin-Lin-Chu and Im-Pesaran-Shin test respectively. All panel statistics are calculated controlling for cross-sectional dependence by subtracting yearly averages as suggested by Im et al. (2003).

Both the individual unit root tests and the Levin-Lin-Chu panel unit root test do not reject the null hypothesis of a unit root. Even at a $10 \%$ level the null is never rejected for any of the cities in the sample. The Im-Pesaran-Shin test on the other hand does not reject the unit root null only at a $1 \%$ level hereby providing some weaker evidence in favor of Gibrat's Law. This would suggest overwhelming evidence in favor of Gibrat's Law with all cities seemingly growing independent of their size.

However, there is one major caveat when drawing this conclusion from these standard unit root tests and that is (maybe not surprisingly) the WWII shock. 
As shown before, the large and sudden impact of WWII had a tremendous effect on the German urban landscape with large cities losing more population more systematically in comparison to the smallest cities in Germany. When performing a standard unit root test one implicitly assumes that the whole effect of this destruction during the war can be viewed as a one-time extreme realization from the distribution of the error term, i.e. $\epsilon_{t}$ in (10). This however seems somewhat unlikely, instead the war can be argued to have had a more substantial impact changing the deterministic components of city size growth, i.e. the constant and/or trend in (10). If this would be the case, to ignore it when performing a standard unit root test results in an underrejection of the unit root null hypothesis (see Perron, 1989 and Perron, 1997). This would imply that Gibrat's Law is potentially overaccepted by standard unit root tests in the case of German city sizes!

To allow for the possibility of a change in the deterministic components of city size growth, we follow Perron (1997) and estimate the following equation:

$\Delta \ln S_{t}=c+\theta_{1} D U_{t}+\zeta t+\theta_{2} D T_{t}+\theta_{3} D\left(T_{b}\right)_{t}+\rho \ln S_{t-1}+\sum_{j=1}^{p} \beta_{i j} \Delta \ln S_{t-j}+\epsilon_{t}$

where $D U_{t}=1\left(t>T_{b}\right), D T_{t}=1\left(t>T_{b}\right) t$ and $D\left(T_{b}\right)_{t}=1\left(t=T_{b}+1\right)$ and $T_{b}$ is the time at which the change occurs. The null hypothesis still remains that of a unit root, the alternative however changes from the series being stationary around a deterministic trend to the series being stationary around a deterministic trend that is allowed to change at time $T_{b}$. The exact timing of the break date is determined endogenously by the data, see Perron, 1997 for details and Hansen, 2001 for a discussion. We choose this procedure over the option of exogenously setting the break date at WWII to allow for the possibility that other events that could have had a major impact on German city sizes during our sample period. Like, for example, the separation from and subsequent reunion with East Germany (see Redding and Sturm, 2005), which may have left a bigger mark on the evolution of some of the cities in our sample.

The results of these unit root tests when we allow for a one-time break are also shown in Table 8. The impact of allowing for a one-time break in the deterministic components of city growth is quite striking. Instead of accepting the null of a unit root for all cities in our sample as the standard unit root tests did, now the unit root null is rejected for $74.2 \%$ of the cities in favor of these series being trend-stationary with a one-time shift in this trend. The date at which the break occurs is almost exclusively found at WWII, which shows that WWII's impact on city sizes is overwhelming other historic events affecting German cities during the second half of the 20th century ${ }^{15}$. The high rejection rate of the unit root null hypothesis also implies that the relevance of Gibrat's Law which seemed evident based on the standard unit root tests gets a substantial blow. Correcting for the impact of WWII on the evolution

\footnotetext{
${ }^{15}$ This is confirmed when doing the unit root tests on only the post-WWII period, resulting in already accepting the unit root hypothesis for about only $38 \%$ of the cities without allowing for a break in the series. Also the analysis allowing for a break did not point out the separation or unification of the two Germany's as clearly as WWII for the whole sample period.
} 
of individual city size Gibrat's Law is found to hold only for about $\frac{1}{4}$ th of the sample.

Together with the evidence obtained using nonparametric methods in the previous section, this dynamic evidence on Gibrat's Law sheds substantial doubt on the relevance of random city size growth in case of Germany, especially for the post-WWII period. Instead the data seem to indicate that city growth does depend on size, with smaller cities growing faster than larger ones. This would constitute evidence that maybe other theories of urban city growth are more relevant to explain the post-WWII experience of the German urban landscape. The faster growth of smaller cities would comply more to theories of urban growth exhibiting increasing and/or decreasing returns to scale and not constant returns to scale as random city growth does. As the post-WWII and pre-WWII period are so different with respect to the implications regarding the relevance of urban economic theories, the war seems to have had a crucial (initializing) role in the changing of both the type and evolution of the German urban landscape. Having found compelling evidence on the irrelevance of random city growth as an explanation of the evolution of the German urban system, the next section, building on earlier work by Davis and Weinstein (2002) and Brakman et al. (2004), provides additional evidence based on the evolution of relative city sizes, i.e. the position of cities within the city size distribution, by which we try to distinguish between the two other competing theories of urban growth, namely increasing returns to scale and locational fundamentals.

\section{Unit root testing and WWII's impact on rel- ative German city sizes}

In previous work, Brakman et al. (2004) and Bosker et al. (2005), we already looked at the immediate impact of WWII on German relative city size. These two papers draw heavily on the methodology developed by Davis and Weinstein $(2002,2004)$ for the case of WWII and Japanese cities. The empirical framework used to identify the impact of the bombing raids and subsequent allied land invasion on relative German city size is the following. Arguing that the bombings were largely exogenous to the level of economic activity in cities, we collected data on the level of destruction during WWII and use that as instruments for population growth during WWII when estimating the following equation:

$$
\Delta s_{\text {post-WWII }}=\alpha \Delta s_{W W I I}+X \beta+\epsilon
$$

where s denotes city size relative to total German population, i.e. $S / S_{t o t}, \mathrm{X}$ are other exogenous variables that can be included in the regression and $\epsilon$ is a random error term. Estimating this equation for Germany, Brakman et al. (2004) using postwar city growth up to 1963 as dependent variable find an $\alpha$ of about 0.5-0.6 which indicates that the average German city in 1963 had returned to a relative city size of about $60 \%$ of the pre-WWII level. Following Davis and Weinstein (2004), Bosker et al. (2005) extend this simple framework by estimating a threshold regression in the spirit of Hansen (2000) hereby allowing for the possibility of multiple equilibria. Assuming the WWII shock has completely petered out by the mid 1960s, they find evidence for the existence of two 
different equilibria, with the least destructed cities shifting to an equilibrium characterized by a larger relative city size.

This evidence thus suggests that the average German city did not fully recover from the WWII shock. Instead, its population in 1963, 18 years after the end of the war, is about $60 \%$ of what it was in 1939. The results in Bosker, et al. (2005) allowing for multiple equilibria confirm our kernel estimates in Figure $3 \mathrm{c}$, indicating that smaller cities suffered less during WWII. However the proposed framework, i.e. estimating $(12)^{16}$ is subject to some caveats. First, the estimation results are sensitive to the choice of period over which post-WWII growth is calculated. Second, the estimation results are only able to describe the impact of WWII on the average German city, they are (only when the fit of the regression is perfect, which it is clearly not) unable to say something about the individual experience of a particular city. The experience of the average city can even be argued to be of secondary importance when the fit of the regression is far from being perfect. Third, and most important, the estimation of (12) is merely a static cross-section regression. Concluding that relative city sizes are mean reverting or random over time is impossible on the basis of such a simple cross-section. Instead, as argued by Hohenberg (2004) the historical evolution of the urban structure must always be studied in terms of fully dynamic models. This is exactly what we purport to do here. Exploiting the long time dimension of our data set, we are able to look at the evolution of individual city's relative size employing fully dynamic econometric estimation techniques.

Both Davis and Weinstein (2002) and Brakman et al. (2004) already mention the fact that the proper test for the persistence of shocks would be performing unit root tests on relative city shares. They refrain from doing this and instead resort to the static framework in (12) on the basis of the earlier mentioned low power of these unit root tests in small samples. Here we are better able to apply such unit root tests for the cities in our sample, as our data set does have a substantial number of observations over time which increases the confidence in the power of the performed test. More specifically we estimate the following equation for each of the cities in our sample:

$$
\Delta s_{t}=\xi+\zeta s_{t-1}+\sum_{i=1}^{p} \Delta s_{t-i}+\nu
$$

where $\mathrm{s}$ is the share of a particular city in total German population, the lagged values of city growth included in the regression control for potential autocorrelation and $\nu$ is a random error component. If $\zeta$ is found to be significantly smaller that 0 , city share is stationary around $\xi$ and any shock will not have a lasting effect. If on the other hand $\zeta$ is found to be equal to 0 then all shocks are permanent and city share follows a random walk. We estimate (12) applying Augmented Dickey Fuller tests to all of the cities in our sample. Table 9 below shows the results of these tests. The table also includes the results of the earlier mentioned Levin-Lin-Chu and Im-Pesaran-Shin panel unit root tests.

The result of the individual city share unit root tests and the Levin-Lin-Chu panel unit root test, are at odds with the notion of city shares being stationary

\footnotetext{
${ }^{16}$ The same holds for the extended version allowing for multiple equilibria.
} 
Table 9: Results unit root tests on city shares in total German population

a: City specific tests

\begin{tabular}{ccc} 
alternative hypothesis: & mean stationary & mean stationary with break \\
\hline significance level & \%unit root rejected & \%unit root rejected \\
$1 \%$ & $0 \%$ & $25.8 \%$ \\
$5 \%$ & $1.6 \%$ & $27.4 \%$ \\
$10 \%$ & $4.8 \%$ & $30.6 \%$ \\
\hline
\end{tabular}

b: Panel tests

\begin{tabular}{lcc} 
& test-statistic (p-value) & test-statistic \\
\hline Levin-Lin-Chu & $-4.259(0.000)$ & \\
Im-Pesaran-Shin & $-0.542(0.302)$ &
\end{tabular}

Notes: The null hypothesis is in all cases a unit root in city share. Following the suggestion in $\mathrm{Ng}$ and Perron (1995) we choose the optimal number of lagged growth rates to be included in the regression to control for autocorrelation using a 'general-to-specific procedure' based on the $\mathrm{t}$ statistic. The maximum lag length to start off this procedure is set at 11 . The panel test statistics are the $t^{*}$ and the $\bar{Z}$ statistic in case of the Levin-Lin-Chu and Im-Pesaran-Shin test respectively. All panel statistics are calculated controlling for cross-sectional dependence by subtracting yearly averages as suggested by Im et al. (2003).

over time ${ }^{17}$. The null hypothesis of a unit root in city share is accepted for almost all cities in the sample. However, as was the case in our earlier unit root tests on city sizes in the previous subsection, this conclusion does not take the possible different effect of WWII into account. Also in case of city shares, the major impact of WWII could have resulted in a shift in the deterministic component of city share, that is the mean $\xi$. To allow for this possibility we apply the following unit root test suggested by Perron and Vogelsang (1992) which allows for a one time break in the mean of the series $\xi$ (endogenously determined by the data) and is based on the estimate of $\zeta$ in the following regression:

$$
\bar{s}_{t}=\zeta \bar{s}_{t-1}+u_{t}
$$

where $u_{t}$ is the random error term and $\bar{s}_{t}$ are the residuals of a regression that projects $s_{t}$ on the deterministic component, i.e. a mean that is allowed to shift at time $T_{b}$. More formally:

$$
s_{t}=\mu+\gamma D U_{t}+\eta
$$

where $D U_{t}=1$ if $t>T_{b}$ and 0 otherwise. Estimating $\zeta$ in this way controls for the possible one-time shift in the deterministic mean in the 'first stage' of the procedure (14) and estimates the autoregressive parameter, $\zeta$ in the 'second

\footnotetext{
${ }^{17}$ The fact that the Im-Pesaran-Shin test rejects the null of all city share having a unit root. However as the alternative of this test is that some cities are stationary and some are not this does not seem to save the pessimistic conclusion regarding the stationarity of city shares.
} 
stage' (15). Perron, 1990 called this the additive outlier (AO) model, which is appropriate to model a sudden one-time change such as the destruction caused by the heavy bombardments during WWII. Perron and Vogelsang (1992) discuss the appropriate test statistics when testing for $\zeta=1$.

The results of applying the AO-model to test for a unit root in German city shares under the null versus stationary city shares around a possibly shifting mean are also shown in Table 11. As was the case for unit root tests on city sizes, the effect of taking account of the possible special nature of the WWIIshock (i.e. having an impact on the deterministic components of city shares) is quite substantial. At a $5 \%$ confidence level the unit root null hypothesis is rejected in favor of a stationary city share with a one-time break for $27 \%$ of the cities in our sample. Even more striking is the fact that for all the cities that are stationary, the timing of the break is (endogenously) found to be WWII. As in the unit root tests on city sizes, allowing for a one-time break in the deterministic component(s) the impact of WWII overshadows the effects of the other historic events (most noteworthy the separation from and unification with East-Germany) that could have had their impact on the evolution of individual cities and the city size distribution as a whole.

The evidence provided in Table 9 constitutes evidence against theories that fall under the locational fundamentals category. The 'standard' unit root tests reject stationarity of city shares for all cities in our sample except one (Hamm). Stationarity of city sizes is accepted for a much larger proportion of the cities in our sample once the deterministic mean around which a particular city is stationary is allowed to change during WWII. This does however not save the locational fundamentals theories as being relevant in the case of Germany. Still random shocks have a persistent effect on the relative city share of more than $70 \%$ of the cities in our sample. Furthermore, although random shocks are not persistent in the case of the cities that are found to be stationary, the extreme shock of WWII did have a lasting effect on the city share of those cities by changing the deterministic mean around which the city share is stationary ${ }^{18}$. This dynamic evidence on the effect of the large shock experienced during WWII ${ }^{19}$ hereby constitutes considerable evidence against the relevance of locational fundamentals theories in explaining the evolution of the German urban landscape. The relevance of the other theories (random growth and increasing returns to scale) is somewhat harder to assess using the results of the unit root tests in this section.

\section{Conclusions}

Remarkably most of the empirical literature on city size distributions has focused on the USA. This is very interesting by itself, but other countries might experience a different evolution of their city size distribution, as this paper shows to be the case for West-Germany. Using a unique annual data set that covers

\footnotetext{
${ }^{18}$ This in fact is corroborated in Bosker, et al. (2005).

${ }^{19}$ As the unit root tests only find the break in deterministic mean without giving any reason why this break occurs (other than the date at which the break occurs), in Appendix B we will tentatively look into some characteristics that may distinguish these 17 cities $(27 \%$ of our sample) from the other cities in the sample.
} 
most of the 20th century for 62 of West-Germany's largest cities, we look at the evolution of both the city size distribution as a whole and each city separately. The West-German case is of particular interest as it has undergone major shocks, most notably WWII. Our data set allows us to identify these shocks and provide evidence on the effects of these 'quasi-natural experiments' on the city size distribution and use this evidence to distinguish between three competing theories that explain urban growth. Also a major contribution of this paper is that we perform unit-root tests on individual German city sizes using a substantial number of observations to find evidence on the relevance of Gibrat's Law. Our main findings are twofold. First, WWII has had a major and lasting impact on the German city size distribution. Second, the overall city size distribution does not adhere to Zipf's Law. This second finding is largely based on the results of unit root tests for individual cities to test for Gibrat's Law, the latter being a requirement for Zipf's Law to hold for the overall city size distribution. Together these two findings are consistent with theories emphasizing increasing returns to scale in city growth. However we have not provided a proper test for this type of theory, concluding only in favor of it given the empirical evidence against the other two theories. Developing a proper test of urban growth theories exhibiting increasing returns is in our view a fruitful area of future research. 


\section{References}

Anderson, G. and Y. Ge, 2005. The size distribution of Chinese cities. Regional Science and Urban Economics 35, p.756-76.

Auerbach, F., 1913. Das Gesetz der Bevölkerungskonzentration. Petermanns Geographische Mitteilungen 59, p.74-76.

Black, D. and V. Henderson, 2003. Urban evolution in the USA. Journal of Economic Geography 3, p.343-72.

Bosker, E.M., Brakman, S., Garretsen, H. and M. Schramm, 2005. Looking for multiple equilibria when geography matters: German city growth and the WWII shock. CESifo working paper no. 1553, CESifo, Munich.

Brakman S., H. Garretsen and C. van Marrewijk, 2001. An introduction to geographical economics. Cambridge University Press, Cambridge, UK.

Brakman, S., Garretsen, H. and M. Schramm, 2004. The strategic bombing of German cities during World War II and its impact on city growth. Journal of Economic Geography 4, p.201-18.

Clark, S.J. and J.C. Stabler, 1991. Gibrat's Law and the growth of Canadian cities. Urban Studies 28, p.635-39.

Córdoba, J.-C., 2004. On the distribution of city sizes. Working paper, Rice university.

Davis, D.R. and D.E. Weinstein, 2002. Bones, bombs and breakpoints: the geography of economic activity. American Economic Review 92, p.1269-89.

Davis, D.R. and D.E. Weinstein, 2004. A search for multiple equilibria in urban industrial structure. NBER working paper no. 10252.

Dickey, D.A. and W.A. Fuller, 1981. Likelihood ratio statistics for autoregressive time series with a unit root. Econometrica 49, p.1057-72.

Dobkins, L.H. and Y.M. Ioannides, 2000. Dynamic evolution of the U.S. city size distribution. In: J.M. Huriot and J.F. Thisse (eds), The Economics of Cities. Cambridge University Press.

Eaton, J. and Z. Eckstein, 1997. Cities and growth: theory and evidence from France and Japan. Regional Science and Urban Economics 27, p.443-74.

Eeckhout, J., 2004. Gibrat's Law for all cities. The American Economic Review 94, p.1429-51.

Embrechts, P., Kluppelberg, P. and T. Mikosch, 1997. Modelling extremal events for insurance and finance. Springer, New York.

Fujita, M., Krugman, P. and A. Venables, 1999. The spatial economy. MIT Press, Cambridge, MA.

Gabaix, X., 1999. Zipf's Law for cities: an explanation. Quarterly Journal of Economics 114, p.739-67.

Gabaix, X. and Y.M. Ioannides, 2004. The evolution of city size distributions. In J.V. Henderson and J.F. Thisse (eds), Handbook of urban and regional economics, Vol 4. Amsterdam: Elsevier Science, North-Holland.

Hansen, B., 2000. Sample splitting and threshold regression. Econometrica 69, p. $575-603$. 
Hansen, B., 2001. The New Econometrics of Structural Change: Dating breaks in U.S. Labor Productivity. Journal of Economic perspectives 15, p.117-28.

Henderson, J.V., 1974. The types and sizes of cities. American Economic Review 64, p.640-56.

Hohenberg, P.M., 2004. The historical geography of European cities: an interpretive essay. In J.V. Henderson and J.F. Thisse (eds), Handbook of urban and regional economics, Vol 4. Amsterdam: Elsevier Science, North-Holland.

Im, K.S., Pesaran, M.H. and Y. Shin, 2003. Testing for unit roots in heterogeneous panels. Journal of Econometrics 115, p.53-74.

Ioannides, Y.M. and H.G. Overman, 2003. Zipf's Law for cities: an empirical examination. Regional Science and Urban Economics 33, p.127-37.

Levin, A., Lin, C.-F. and C.-S.J. Lin, 2002. Unit root tests in panel data: asymptotic and finite-sample properties. Journal of Econometrics 108, p. 1-24.

Ng, S., and P. Perron, 1995. Unit Root Tests in ARMA Models with Data Dependent Methods for the Selection of the Truncation Lag. Journal of the American Statistical Association 90, p.268-81.

Nitsch, V., 2005. Zipf zipped. Journal of Urban Economics 57, p.86100

Overman, H.G. and Y.M. Ioannides, 2001. Cross-sectional evolution of the U.S. city size distribution. Journal of Urban Economics 49, p.543-66.

Perron, P., 1989. The Great Crash, the oil price shock, and the unit root hypothesis. Econometrica 57, p.1361-1401.

Perron, P., 1997. Further evidence on breaking trend functions in macroeconomic variables. Journal of Econometrics 80, p.355-85.

Perron, P. and T.J. Vogelsang, 1992. Testing for a unit root in time series with a changing mean: corrections and extensions. Journal of Business \& Economic Statistics 10, p.467-72.

Quah, D., 1993. Empirical cross-section dynamics and economic growth. European Economic Review 37, p.426-34.

Redding, S. and D.M. Sturm, 2005. The Costs of Remoteness: Evidence from German Division and Reunification. CEPR discussion paper no. 5015, London.

Rossi-Hansberg, E. and M.L.J. Wright, 2005. Urban structure and economic growth. Working paper, Stanford University.

Silverman, B.W., 1986. Density Estimation for Statistics and Data Analysis. Chapman and Hall, London.

Simon, H., 1955. On a class of skew distribution functions. Biometrika 44, p. $425-440$.

Soo, K.T., 2005. Zipf's Law for cities: a cross-country investigation. Regional Science and Urban Economics 35, p.239-63.

Zipf, G.K., 1949. Human behavior and the principle of least effort. AddisonWesley, Cambridge, MA. 


\section{A Data}

Table 10 below gives an overview of the 62 cities included in our sample.

Table 10: West-German sample cities

$\begin{array}{lll}\text { Berlin West } & \text { Braunschweig } & \text { Heidelberg } \\ \text { Hamburg } & \text { Mönchengladbach-Rheydt } & \text { Würzburg } \\ \text { München } & \text { Münster } & \text { Recklinghausen } \\ \text { Köln } & \text { Augsburg } & \text { Remscheid } \\ \text { Frankfurt am Main } & \text { Kiel } & \text { Regensburg } \\ \text { Essen } & \text { Krefeld } & \text { Bottrop } \\ \text { Dortmund } & \text { Aachen } & \text { Offenbach am Main } \\ \text { Düsseldorf } & \text { Oberhausen } & \text { Pforzheim } \\ \text { Stuttgart } & \text { Lübeck } & \text { Ulm } \\ \text { Bremen } & \text { Hagen } & \text { Koblenz } \\ \text { Duisburg } & \text { Kassel } & \text { Witten } \\ \text { Hannover } & \text { Freiburg im Breisgau } & \text { Hildesheim } \\ \text { Nürnberg } & \text { Hamm } & \text { Fürth } \\ \text { Bochum } & \text { Mainz } & \text { Kaiserslautern } \\ \text { Wuppertal } & \text { Herne } & \text { Trier } \\ \text { Bielefeld } & \text { Mülheim an der Ruhr } & \text { Wanne-Eickel } \\ \text { Mannheim } & \text { Solingen } & \text { Bamberg } \\ \text { Gelsenkirchen } & \text { Osnabrück } & \text { Gladbeck } \\ \text { Bonn } & \text { Ludwigshafen am Rhein } & \text { Wattenscheid } \\ \text { Karlsruhe } & \text { Oldenburg } & \text { Flensburg } \\ \text { Wiesbaden } & \text { Darmstadt } & \\ & & \end{array}$

These cities are included out of a total of 81 cities in the original data set ${ }^{20}$ on the basis of the availability of annual city population data over the period 1925-1999. The cities that were left out of the original data set were dropped on the basis of failing to comply to one (or more) of the following criteria:

1. More than two consecutive years with no population data.

2. Not able to correct for a so-called Gemeindereform, i.e. local government reorganization, that occurred in the early 1930s for several cities in the industrial Ruhr-area and for most of the sample cities during the 1970s.

The first exclusion criteria results in about 16 cities to be excluded from the data set. If at most two observations are missing we construct the city population for the missing years by interpolating (such a correction is made only 6 times). The other 3 are excluded based on the second criteria. Most cities in our data set are affected by the Gemeindereform of the 1970s and most cities in the Ruhr-area also by the Gemeindereform in the 1930s. In order to have the same unit of analysis in terms of city boundaries we have decided to take the city boundaries

\footnotetext{
${ }^{20}$ For a detailed description of the original data set and its sources see Brakman et al. (2004).
} 
at the time of WWII as a point of reference. For example if due to a local government reorganization an adjacent town becomes part of one of the cities in our sample we extend this city boundary redefinition to all pre-WWII years if this redefinition happened before WWII and we ignore it if it happened after WWII. The fact that for most of the cities in our sample the exact number of people that is added due to a local government reorganization is recorded in the Statistical Yearbooks allows us to correct for this quite accurately. More formally in case of a pre-WWII Gemeindereform at time $\mathrm{T}$ we adapt the series as follows,

$$
\tilde{S}_{T-k}=S_{T} \frac{S_{T-k}}{\left(S_{T}-S_{\text {new }}\right)}
$$

where $S_{T}$ is the population at time T including the newly added towns, $S_{\text {new }}$ is the number of people living in the newly added towns, $S_{T-k}$ is the city population as reported in year T-k, i.e. before the city boundary redefinition, and $\tilde{S}_{T-k}$ is the newly calculated, as if the new city boundary was already in affect, city population at time T-k. If instead a city was subject to a post-WWII Gemeindereform this is incorporated as,

$$
\begin{gathered}
\tilde{S}_{T}=S_{T}-S_{\text {new }} \\
\tilde{S}_{T+k}=\tilde{S}_{T} \frac{S_{T+k}}{S_{T}}
\end{gathered}
$$

where $S_{T}$ and $S_{n e w}$ are defined as above and $\tilde{S}_{T}\left(\tilde{S}_{T+k}\right)$ is the newly calculated, as if city boundary redefinition did not happen, city population at time $\mathrm{T}(\mathrm{T}+\mathrm{k})$. Thus the crucial assumption made in case of a pre-WWII Gemeindereform is that the city's and its newly added town's population grew at the same rate before the reform. Similarly in case of a post-WWII Gemeindereform the crucial assumption is that after the Gemeindereform the city's and its newly added town's population grew at the same rate.

\section{B City characteristics}

The unit root tests in section 6 indicated that 17 cities experienced a one-time substantial impact of WWII on the share of their population in total German population. It turns out that 15 of these 17 cities experienced a negative impact of the WWII shock. To give some indication about possible differences between the break-stationary and the nonstationary cities, Table 11 below shows the mean and standard deviation of several characteristics for 1) the 17 break stationary, 2) the 45 nonstationary cities. Also included are the results of a simple test of the equivalence of the means of the two groups given their variances and the final column contains this test when focussing only on the cities with a negative break in their city share.

The tests for a significant difference in the mean of the characteristics show some interesting results. Cities that have experienced a break in the deterministic mean of their city's share in total German population have been hit significantly 
Table 11: City characteristics

\begin{tabular}{|c|c|c|c|c|c|c|}
\hline & \multicolumn{2}{|c|}{ break stationary } & \multicolumn{2}{|c|}{ nonstationary } & \multirow[b]{2}{*}{ t-test } & \multirow{2}{*}{$\begin{array}{r}\text { neg.break } \\
\text { t-test }\end{array}$} \\
\hline & mean & s.d. & mean & s.d. & & \\
\hline \multicolumn{7}{|l|}{ War-related } \\
\hline$\%$ housing destroyed & 50.88 & 17.56 & 35.26 & 16.77 & 3.163 & 6.020 \\
\hline m3 rubble per capita & 20.46 & 6.56 & 9.81 & 7.00 & 5.480 & 5.256 \\
\hline reconstruction aid & 0.01 & 0.01 & 0.01 & 0.01 & 0.734 & 0.887 \\
\hline \% refugees 1960 & 0.15 & 0.04 & 0.17 & 0.04 & -2.043 & -2.834 \\
\hline \multicolumn{7}{|l|}{ Geography-related } \\
\hline$D_{\text {München }}$ & 366.24 & 128.96 & 419.38 & 165.19 & -0.175 & -0.169 \\
\hline$D_{\text {Hamburg }}$ & 380.82 & 98.82 & 329.62 & 151.59 & -0.485 & -0.862 \\
\hline$D_{K o ̈ l n}$ & 155.08 & 93.61 & 182.87 & 141.03 & 0.036 & 0.083 \\
\hline $\min D_{\text {East-Germany }}$ & 178.83 & 65.48 & 182.96 & 64.03 & -0.686 & -1.111 \\
\hline City-size related & & & & & & \\
\hline size pre-WWII & 369250 & 640162 & 241725 & 289447 & 0.791 & 0.903 \\
\hline growth pre-WWII & -0.03 & 0.06 & -0.02 & 0.08 & -0.511 & -1.055 \\
\hline growth WWII & -0.29 & 0.20 & -0.12 & 0.18 & -3.027 & -6.316 \\
\hline growth post-WWII & 0.13 & 0.20 & -0.07 & 0.22 & 3.408 & 3.633 \\
\hline
\end{tabular}

more severe during the war. The percentage of the housing stock destroyed is $15 \%$ higher and the amount of rubble per capita $11 \mathrm{~m} 3$ higher than for cities with a random evolution of their city share. This shows that these cities have suffered substantially more as a results of the massive bombardments during the war. Another interesting, possibly related, finding is that after the war these cities have had a lesser inflow of refugees than the cities with a nonstationary city share. The city-size related characteristics confirm the notion that in those cities with a shift in relative city share more war damage resulted in a larger decline of this relative city share during the war. Mean WWII-growth is significantly less for these cities (-29\% vs. $-12 \%)$. What is interesting is that although post-WWII growth is larger for these same cities, this higher growth does not compensate for the losses suffered during WWII, hereby resulting in a permanent impact on relative city share. Another interesting thing to notice is that pre-WWII city size (1939) does not differ significantly between the two groups of $\operatorname{cities}^{21}$. Finally the cities are also compared on the basis of several geography-related characteristics. However distance from the later East-German border or to one of Germany's economic centers (Hamburg, München or the industrial Ruhr-area, Köln) does not differ significantly between the two groups.

\footnotetext{
${ }^{21}$ The final column of Table 11 shows that these results are even more profound when focussing only on the negative city share breaks.
} 


\section{CESifo Working Paper Series}

(for full list see www.cesifo-group.de)

1665 Samuel Muehlemann and Stefan C. Wolter, Regional Effects on Employer Provided Training: Evidence from Apprenticeship Training in Switzerland, February 2006

1666 Laszlo Goerke, Bureaucratic Corruption and Profit Tax Evasion, February 2006

1667 Ivo J. M. Arnold and Jan J. G. Lemmen, Inflation Expectations and Inflation Uncertainty in the Eurozone: Evidence from Survey Data, February 2006

1668 Hans Gersbach and Hans Haller, Voice and Bargaining Power, February 2006

1669 Françoise Forges and Frédéric Koessler, Long Persuasion Games, February 2006

1670 Florian Englmaier and Markus Reisinger, Information, Coordination, and the Industrialization of Countries, February 2006

1671 Hendrik Hakenes and Andreas Irmen, Something out of Nothing? Neoclassical Growth and the 'Trivial' Steady State, February 2006

1672 Torsten Persson and Guido Tabellini, Democracy and Development: The Devil in the Details, February 2006

1673 Michael Rauber and Heinrich W. Ursprung, Evaluation of Researchers: A Life Cycle Analysis of German Academic Economists, February 2006

1674 Ernesto Reuben and Frans van Winden, Reciprocity and Emotions when Reciprocators Know each other, February 2006

1675 Assar Lindbeck and Mats Persson, A Model of Income Insurance and Social Norms, February 2006

1676 Horst Raff, Michael Ryan and Frank Staehler, Asset Ownership and Foreign-Market Entry, February 2006

1677 Miguel Portela, Rob Alessie and Coen Teulings, Measurement Error in Education and Growth Regressions, February 2006

1678 Andreas Haufler, Alexander Klemm and Guttorm Schjelderup, Globalisation and the Mix of Wage and Profit Taxes, February 2006

1679 Kurt R. Brekke and Lars Sørgard, Public versus Private Health Care in a National Health Service, March 2006

1680 Dominik Grafenhofer, Christian Jaag, Christian Keuschnigg and Mirela Keuschnigg, Probabilistic Aging, March 2006 
1681 Wladimir Raymond, Pierre Mohnen, Franz Palm and Sybrand Schim van der Loeff, Persistence of Innovation in Dutch Manufacturing: Is it Spurious?, March 2006

1682 Andrea Colciago, V. Anton Muscatelli, Tiziano Ropele and Patrizio Tirelli, The Role of Fiscal Policy in a Monetary Union: Are National Automatic Stabilizers Effective?, March 2006

1683 Mario Jametti and Thomas von Ungern-Sternberg, Risk Selection in Natural Disaster Insurance - the Case of France, March 2006

1684 Ken Sennewald and Klaus Waelde, "Itô's Lemma“ and the Bellman Equation for Poisson Processes: An Applied View, March 2006

1685 Ernesto Reuben and Frans van Winden, Negative Reciprocity and the Interaction of Emotions and Fairness Norms, March 2006

1686 Françoise Forges, The Ex Ante Incentive Compatible Core in Exchange Economies with and without Indivisibilities, March 2006

1687 Assar Lindbeck, Mårten Palme and Mats Persson, Job Security and Work Absence: Evidence from a Natural Experiment, March 2006

1688 Sebastian Buhai and Coen Teulings, Tenure Profiles and Efficient Separation in a Stochastic Productivity Model, March 2006

1689 Gebhard Kirchgaessner and Silika Prohl, Sustainability of Swiss Fiscal Policy, March 2006

1690 A. Lans Bovenberg and Peter Birch Sørensen, Optimal Taxation and Social Insurance in a Lifetime Perspective, March 2006

1691 Moritz Schularick and Thomas M. Steger, Does Financial Integration Spur Economic Growth? New Evidence from the First Era of Financial Globalization, March 2006

1692 Burkhard Heer and Alfred Maussner, Business Cycle Dynamics of a New Keynesian Overlapping Generations Model with Progressive Income Taxation, March 2006

1693 Jarko Fidrmuc and Iikka Korhonen, Meta-Analysis of the Business Cycle Correlation between the Euro Area and the CEECs, March 2006

1694 Steffen Henzel and Timo Wollmershaeuser, The New Keynesian Phillips Curve and the Role of Expectations: Evidence from the Ifo World Economic Survey, March 2006

1695 Yin-Wong Cheung, An Empirical Model of Daily Highs and Lows, March 2006

1696 Scott Alan Carson, African-American and White Living Standards in the $19^{\text {th }}$ Century American South: A Biological Comparison, March 2006

1697 Helge Berger, Optimal Central Bank Design: Benchmarks for the ECB, March 2006 
1698 Vjollca Sadiraj, Jan Tuinstra and Frans van Winden, On the Size of the Winning Set in the Presence of Interest Groups, April 2006

1699 Martin Gassebner, Michael Lamla and Jan-Egbert Sturm, Economic, Demographic and Political Determinants of Pollution Reassessed: A Sensitivity Analysis, April 2006

1700 Louis N. Christofides and Amy Chen Peng, Major Provisions of Labour Contracts and their Theoretical Coherence, April 2006

1701 Christian Groth, Karl-Josef Koch and Thomas M. Steger, Rethinking the Concept of Long-Run Economic Growth, April 2006

1702 Dirk Schindler and Guttorm Schjelderup, Company Tax Reform in Europe and its Effect on Collusive Behavior, April 2006

1703 Françoise Forges and Enrico Minelli, Afriat’s Theorem for General Budget Sets, April 2006

1704 M. Hashem Pesaran, Ron P. Smith, Takashi Yamagata and Liudmyla Hvozdyk, Pairwise Tests of Purchasing Power Parity Using Aggregate and Disaggregate Price Measures, April 2006

1705 Piero Gottardi and Felix Kubler, Social Security and Risk Sharing, April 2006

1706 Giacomo Corneo and Christina M. Fong, What's the Monetary Value of Distributive Justice?, April 2006

1707 Andreas Knabe, Ronnie Schoeb and Joachim Weimann, Marginal Employment Subsidization: A New Concept and a Reappraisal, April 2006

1708 Hans-Werner Sinn, The Pathological Export Boom and the Bazaar Effect - How to Solve the German Puzzle, April 2006

1709 Helge Berger and Stephan Danninger, The Employment Effects of Labor and Product Markets Deregulation and their Implications for Structural Reform, May 2006

1710 Michael Ehrmann and Marcel Fratzscher, Global Financial Transmission of Monetary Policy Shocks, May 2006

1711 Carsten Eckel and Hartmut Egger, Wage Bargaining and Multinational Firms in General Equilibrium, May 2006

1712 Mathias Hoffmann, Proprietary Income, Entrepreneurial Risk, and the Predictability of U.S. Stock Returns, May 2006

1713 Marc-Andreas Muendler and Sascha O. Becker, Margins of Multinational Labor Substitution, May 2006

1714 Surajeet Chakravarty and W. Bentley MacLeod, Construction Contracts (or "How to Get the Right Building at the Right Price?’), May 2006 
1715 David Encaoua and Yassine Lefouili, Choosing Intellectual Protection: Imitation, Patent Strength and Licensing, May 2006

1716 Chris van Klaveren, Bernard van Praag and Henriette Maassen van den Brink, Empirical Estimation Results of a Collective Household Time Allocation Model, May 2006

1717 Paul De Grauwe and Agnieszka Markiewicz, Learning to Forecast the Exchange Rate: Two Competing Approaches, May 2006

1718 Sijbren Cnossen, Tobacco Taxation in the European Union, May 2006

1719 Marcel Gérard and Fernando Ruiz, Interjurisdictional Competition for Higher Education and Firms, May 2006

1720 Ronald McKinnon and Gunther Schnabl, China's Exchange Rate and International Adjustment in Wages, Prices, and Interest Rates: Japan Déjà Vu?, May 2006

1721 Paolo M. Panteghini, The Capital Structure of Multinational Companies under Tax Competition, May 2006

1722 Johannes Becker, Clemens Fuest and Thomas Hemmelgarn, Corporate Tax Reform and Foreign Direct Investment in Germany - Evidence from Firm-Level Data, May 2006

1723 Christian Kleiber, Martin Sexauer and Klaus Waelde, Bequests, Taxation and the Distribution of Wealth in a General Equilibrium Model, May 2006

1724 Axel Dreher and Jan-Egbert Sturm, Do IMF and World Bank Influence Voting in the UN General Assembly?, May 2006

1725 Swapan K. Bhattacharya and Biswa N. Bhattacharyay, Prospects of Regional Cooperation in Trade, Investment and Finance in Asia: An Empirical Analysis on BIMSTEC Countries and Japan, May 2006

1726 Philippe Choné and Laurent Linnemer, Assessing Horizontal Mergers under Uncertain Efficiency Gains, May 2006

1727 Daniel Houser and Thomas Stratmann, Selling Favors in the Lab: Experiments on Campaign Finance Reform, May 2006

1728 E. Maarten Bosker, Steven Brakman, Harry Garretsen and Marc Schramm, A Century of Shocks: The Evolution of the German City Size Distribution 1925 - 1999, May 2006 